\title{
BIOGENESIS OF PURPLE MEMBRANE: REGULATION OF BACTERIO-OPSIN SYNTHESIS
}

\author{
Manfred SUMPER and Gisela HERRMANN \\ Institut für Biochemie der Universität Würzburg, 87 Würzburg, Röntgenring 11, G.F.R.
}

Received 13 August 1976

\section{Introduction}

In the cell membrane of Halobacteria a photoreceptor protein, bacteriorhodopsin, forms a twodimensional hexagonal crystalline network within the lipid matrix [1-4]. This specialized domain of the membrane has been termed purple membrane $[5,6]$.

Besides its attractiveness for bioenergetic studies, the purple membrane appears highly suited for studying the biogenesis of a membrane: Purple membrane contains only one protein species (bacterioopsin), one pigment (retinal) bound to bacterio-opsin and two main lipid species. Its biogenesis is inducible: A situation of low oxygen supply [7] and/or of nutrient exhaustion triggers the membrane synthesis.

In a recent paper [8] it was shown that (1) the synthesis of both the membrane components bacterioopsin and retinal are strictly coordinated. Only inducing conditions turn on both biosynthetic pathways. (2) Another differentiated domain of the plasma membrane termed the 'brown membrane' is involved in the biogenesis of the purple membrane. This domain has a lower buouyant density than purple membrane, contains bacteriorhodopsin and a cy tochrome $b$-type protein besides lipid and some minor protein species. (3) Newly formed bacterioopsin is initially incorporated in the brown membrane and can only 'crystallize' to form the purple membrane patches after reaction with retinal and a subsequent modification step.

\section{Materials and methods}

\subsection{Halobacteria strain and media}

Growth of the mutant $R_{1} M_{1}$ of $H$. halobium which does not synthesize bacterioruberin was performed as described in ref. [9]. Basal salt solution contained per liter $250 \mathrm{~g} \mathrm{NaCl}, 20 \mathrm{~g} \mathrm{MgSO}_{4} \cdot 7 \mathrm{H}_{2} \mathrm{O}$ and $2 \mathrm{~g} \mathrm{KCl}$.

\subsection{Growth conditions inducing purple membrane production}

Large scale: 14 liter Magnaferm fermenter (New Brunswick); aeration $120 \mathrm{liter} / \mathrm{min}, 300 \mathrm{rev} / \mathrm{min}, 39^{\circ} \mathrm{C}$ Small scale: $230 \mathrm{ml}$ medium in a $500 \mathrm{ml}$ Erlenmeyer flask or $10 \mathrm{ml}$ in a $25 \mathrm{ml}$ Erlenmeyer flask, shaken with 100 reciprocating movements per min. These conditions of limited oxygen supply will be denoted in the following as 'standard conditions'.

Sufficient aeration (nearly no purple membrane production) occurs if the fermenter is run at 180 liter air/min and $500 \mathrm{rev} / \mathrm{min}$ or a $500 \mathrm{ml}$ Erlenmeyer fask is filled with only $90 \mathrm{ml}$ medium under otherwise identical conditions.

\subsection{Isolation of the membrane fractions}

Cells were lyzed in $0.2 \mathrm{M} \mathrm{NaCl}$ solution. A small amount of DNase was added to reduce viscosity. The lyzate was centrifuged in a Beckman $50 \mathrm{Ti}$ rotor at $35000 \mathrm{rev} / \mathrm{min}$ for $2 \mathrm{~h}$. The sedimented membrane fractions were resuspended and analyzed either directly by dodecylsulphate gel electrophoresis or further separated by sucrose density gradient centrifugation (20-45\% sucrose) in a Beckman SW 41 rotor $(36000 \mathrm{rev} / \mathrm{min}, 6-8 \mathrm{~h})$. This procedure yields the membrane fractions RM 340, brown membrane and purple membrane. Spectra were taken with an Aminco DW 2 spectrophotometer.

\subsection{Gel electrophoresis}

Dodecylsulphate gradient gel electrophoresis was performed as described in ref. [10] . A linear gradient (10-25\% acrylamide) was used. 


\section{Results and discussion}

The alkaloid nicotine selectively inhibits synthesis of the purple membrane component retinal [11] by blocking the cyclization of lycopene to $\beta$-carotene [12] In cells grown in the presence of $1 \mathrm{mM}$ nicotine (in the following denoted as 'nicotine cells') production of the purple membrane is completely blocked, synthesis of the membrane protein bacterio-opsin yet remains inducible: Nicotine cells grown under conditions of limited oxygen supply contain 4-5 fold higher levels of bacterio-opsin than aerobically grown nicotine cells. This observation indicates that the signal inducing the cell to produce purple membrane directly controls the protein synthesis of bacterio-opsin.

Bacterio-opsin accumulating in nicotine cells does not form the crystalline lattice of the purple membrane, but is found in another differentiated membrane fraction that was called the brown membrane. Figure 1 shows the membrane protein pattern (fig. 1 A) and some spectroscopic properties (fig.1B and C) of the brown membrane. In addition to bacterio-opsin, one further protein component together with some minor protein species are detectable by dodecylsulphate gel electrophoresis. The absorption spectrum of the brown membrane purified from nicotine cells (fig.1B) displays maxima at $418 \mathrm{~nm}$ and $276 \mathrm{~nm}$ (not shown) in the oxydized form and at $560 \mathrm{~nm}, 527 \mathrm{~nm}, 427 \mathrm{~nm}$ and $276 \mathrm{~nm}$ in the dithionite-reduced form, indicating the presence of a heme protein. Addition of retinal converts the bacterio-opsin of the brown membrane to bacteriorhodopsin, thereby forming the $570 \mathrm{~nm}$ chromophor. Brown membrane preparations isolated from cells grown in the absence of nicotine contain most of their bacterioopsin already complexed with retinal, only about 10-20\% free bacterio-opsin are detectable (fig. 1C).

In order to follow the kinetics of purple membrane formation, nicotine cells containing bacterio-opsin were resuspended in a nicotine-free medium and further incubated at $37^{\circ} \mathrm{C}$. As shown in fig. $2 \mathrm{~A}$, the bacterioopsin of the brown membrane becomes gradually converted to bacteriorhodopsin. Obviously, endogenous retinal synthesis immediately resumes under these conditions. After a lag period of about $2 \mathrm{~h}$ the bacteriorhodopsin of the brown membrane begins to 'crystallize', thereby forming purple membrane patches. If this experiment is repeated in the presence of the uncoupler carbonyl cyanide $m$-chlorophenylhydrazone (CCCP) purple membrane formation is completely

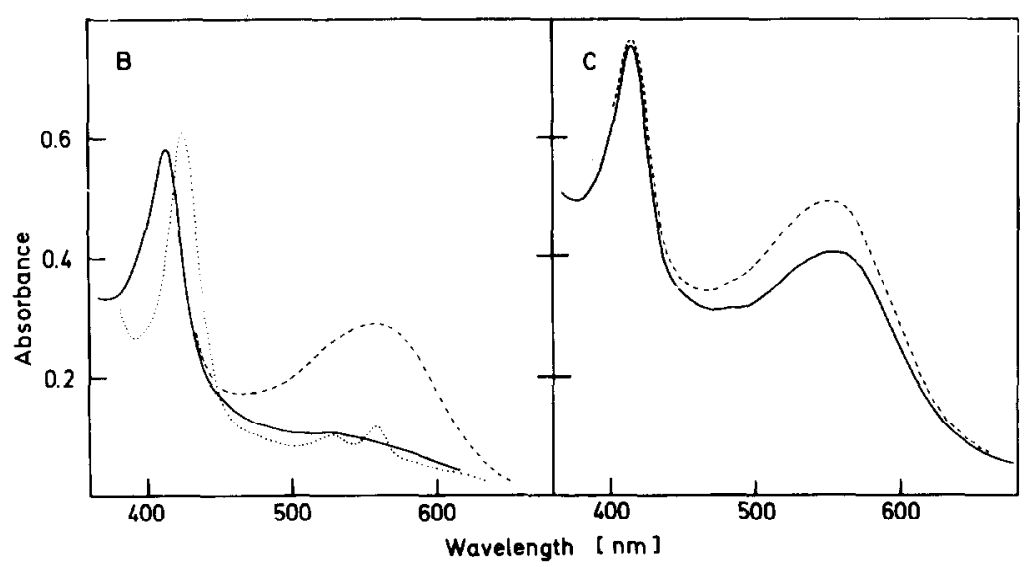

Fig.1 Protein composition and spectral properties of the brown membrane: (A) Dodecylsulphate gradient gel electrophoresis of the brown membrane. (B) Absorption spectrum of the brown membrane isolated from nicotine cells: (- - ) air oxidized form, $(. .$.$) dithionite-reduced form and (...-) air oxidized form after the addition of 15 \mathrm{nmol} / \mathrm{ml}$ all-trans retinal. (C) Absorption spectrum of the brown membrane isolated from cells grown in the absence of nicotine: $\left(-\_\right)$air oxidized form, $(---)$air oxidized form after the addition of $15 \mathrm{nmol} / \mathrm{ml}$ retinal. 


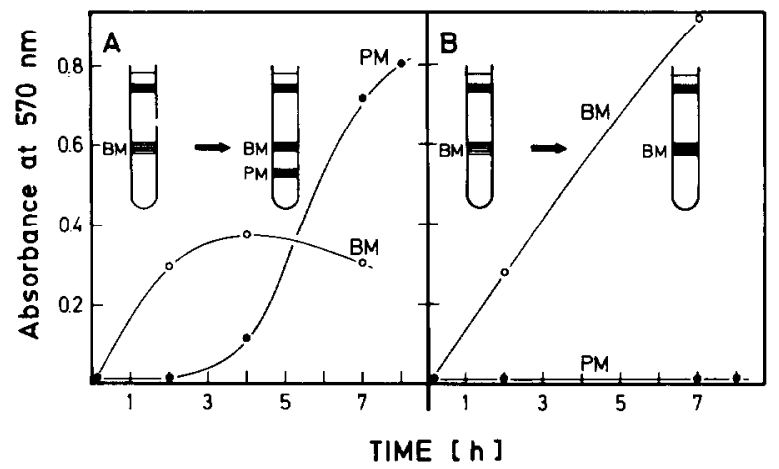

Fig.2. Kinetics of purple membrane formation. Halobacteria were grown in the magnaferm fermenter under stanard conditions. After $90 \mathrm{~h}$, the cells were harvested by centrifugation, washed in basal salt solution and resuspended in basal salt solution containing $0,5 \% \mathrm{~L}$-alanine (cell concentration: $A_{578}=1.5$ ). $200 \mathrm{ml}$ aliquots were shaken in $500 \mathrm{ml}$ Erlenmeyer flasks at $39^{\circ} \mathrm{C}$ for the times indicated. After incubation, the cells were harvested and lyzed. The membrane fractions were separated by sucrose density gradient centrifugation as described in Materials and methods. Brown membrane fractions (BM) and purple membrane fractions (PM) were diluted to $2.0 \mathrm{ml}$ and analyzed spectrophotometrically at $570 \mathrm{~nm}$. (A) incubation in basal salt containing L-alanine. (B) as (A), except for addition of $2 \times 10^{-5} \mathrm{M}$ carbonyl cyanide $m$-chlorophenylhydrazone (CCCP). The inserts show schematically the changes of the membrane patterns (sucrose gradients).

blocked, though the endogenous retinal synthesis again resumes: All the bacterio-opsin present is converted to bactcriorhodopsin, but remains localized in the brown membrane (fig. 2B). The same type of inhibition is observed in the presence of $0.1 \mathrm{mM}$ cyanide. Formation of purple membrane is also blocked by the presence of the protein biosynthesis inhibitor puromycin, though retinal synthesis again remains unaffected. Apparently, an energy-dependent (protein synthesis-dependent) step is involved in the process of sorting out and assembling bacteriorhodopsin in the brown membrane to form the purple membrane patches.

As mentioned above, synthesis of bacterio-opsin remains inducible even under conditions of complete inhibition of retinal synthesis. However, these nicotine cells contain only $20-30 \%$ of the bacterio-opsin present in cells grown in the absence of nicotine but under otherwise identical conditions. This finding suggests that free bacterio-opsin (but not bacteriorhodopsin) is able to inhibit its own synthesis. If this

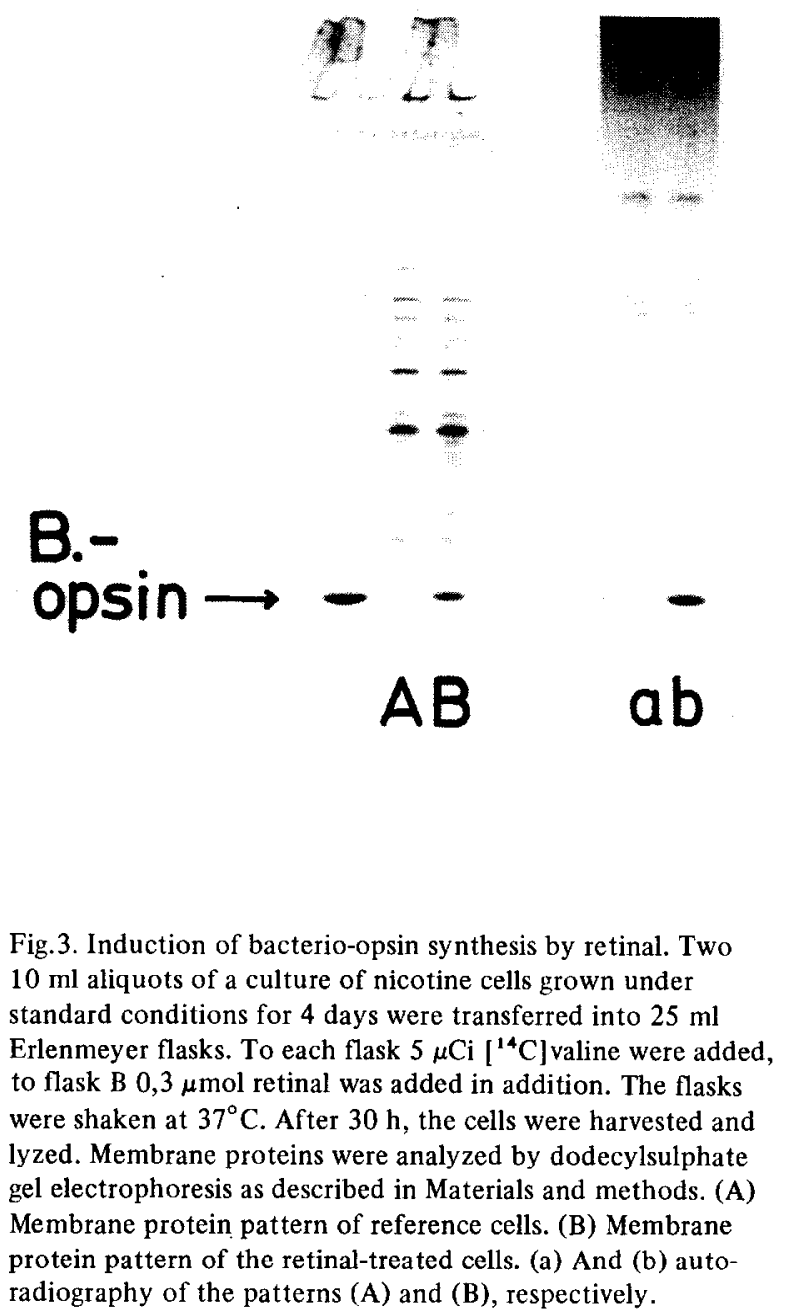

were the case, one would expect that addition of retinal to a culture of nicotine cells would stimulate synthesis of bacterio-opsin. Figure 3 shows the result of such an experiment: One half of a nicotine cell culture of the stationary growth phase was treated with retinal, the other half used as reference. The analysis reveals a nearly 5 -fold stimulation of bacterio-opsin production in the retinal-treated cells. If a labeled amino acid is added together with retinal, bacterioopsin becomes highly labeled (fig. $3 b$ ). Thus retinal stimulates indeed de novo protein synthesis of bacterio-opsin. This conclusion was also reached on the basis of similar experiments using the protein synthesis inhibitor puromycin. Simultaneous addition 
Table 1

Bacteriorhodopsin content of cells grown under different conditions

\begin{tabular}{lllll}
\hline Culture & \multicolumn{2}{l}{ Growth conditions } & $\begin{array}{l}\text { Bacleriorhodopsin } \\
\text { production } \\
\text { (nmol/100 ml culture) }\end{array}$ \\
\cline { 2 - 5 } & High $\mathrm{O}_{2}$ supply & Low $\mathrm{O}_{2}$ supply & $\begin{array}{l}\text { Addition } \\
\text { of retinal }\end{array}$ & \\
\hline 1 & + & - & - & 12 \\
2 & + & - & + & 14 \\
3 & - & + & - & 61 \\
4 & - & + & + & 69 \\
\hline
\end{tabular}

Cells were grown under conditions of limited or high oxygen supply, respective (see Materials and methods). To culture 2 and 4, $0.5 \mathrm{nmol}$ retinal per ml culture were added every $10 \mathrm{~h}$. After 4 days, the cells were harvested and lyzed. The total membrane fraction was analyzed spectroscopically for bacteriorhodopsin content.

of retinal and puromycin $(20 \mu \mathrm{g} / \mathrm{ml})$ to nicotinc cells completely abolish the increase of bacterio-opsin production.

Our results so far demonstrate that bacterio-opsin controls its own synthesis. These results imply that this control is exerted either at the level of transcription (a repressor function of bacterio-opsin) or at the level of translation. The data available at present allow no distinction among these possibilities.

The experimental results obtained so far show the existence of at least two different control mechanisms regulating bacterio-opsin synthesis: (1) Low oxygen concentration induces bacterio-opsin synthesis and (2) free bacterio-opsin inhibits its own synthesis. Retinal cancels this inhibition, thereby inducing bacterio-opsin synthesis. In order to find out the hierarchy of these control functions, the following experiment was made: Halobacteria were grown under conditions of efficient aeration and every $10 \mathrm{~h}$ retinal was added to the culture. Under these conditions, control mechanisms 1 and 2 should regulate in conflicting ways. Mechanism 1 does not allow bacterioopsin synthesis, whereas mechanism 2 allows synthesis. The experimental results summarized in table 1 indicate that the control pathway exerted by oxygen concentration is dominant and determines the maximum rate of opsin synthesis for a given growth condition. It appears plausible that the main job of control mechanism 2 is to coordinate the bacterioopsin and retinal synthetic pathways.

\section{Acknowledgements}

We thank Professor D. Oesterhelt for helpful discussions and support. This work was supported by the Deutsche Forschungsgemeinschaft.

\section{References}

[1] Oesterhelt, D. and Stoeckenius, W. (1971) Nature New Biol. 233, 149-152.

[2] Blaurock, A. E. and Stoeckenius, W. (1971) Nature New Biol. 233, 152-154.

[3] Blaurock, A. E. (1975) J. Mol. Biol. 93, 139-158.

[4] Henderson, R. and Unwin, P. N. T. (1975) Nature 257, 28-32.

[5] Stoeckenius, W. and Rowen, J. (1967) J. Cell. Biol. 34, $365-393$.

[6] Stoeckenius, W. and Kunau, W. H. (1968) J. Cell. Biol. $38,337-357$.

[7] Oesterhelt, D. and Stoeckenius, W. (1973) Proc. Natl. Acad. Sci. USA 70, 2853-2857.

[8] Sumper, M., Reitmeier, H. and Oesterhelt, D. (1976) Angew. Chem. Int. Ed. Engl. 15, 187-194.

[9] Oesterhelt, D. and Stoeckenius, W. (1974) Meth. in Enzymol. 31, 667-678.

[10] Laemmli, U. K. (1970) Nature 227, 680-685.

[11] Reitmeier, H. (1976) Doctoral Thesis, University of Würzburg.

[12] Howes, C. D. and Batra, P. P. (1970) Biochim. Biophys. Acta 222, 174-179. 


\title{
CONFORMATIONAL DYNAMICS OF PORCINE PANCREATIC COLIPASE: A $360 \mathrm{MHz}$ PROTON NUCLEAR MAGNETIC RESONANCE STUDY
}

\author{
Patrick J. COZZONE \\ Institut de Chimie Biologique, Université de Provence, Place Victor Hugo, 13003 Marseille, France
}

Received 6 August 1976

\section{Introduction}

The present study is devoted to colipase II, one of the two main molecular forms of porcine pancreatic colipase $[1,2]$. This small protein has a molecular weight of 8700 and consists of a single polypeptide chain of 84 amino acid residues $[3,4]$. Its amino acid sequence has been determined [3] and corresponds to a rather compact structure maintained by 5 disulfide bridges [4]. The biological role of colipase is of great importance since it acts in vivo as a cofactor preventing the inhibitory effect of physiological concentrations of bile salts on the intraduodenal lipolysis of dietary triglycerides $[1,5,6]$. In an attempt to explain the physiological effect of colipase, binary and ternary associations of colipase, lipase and bile salts have been recently investigated under a variety of experimental conditions [7-13]. Typically, colipase has been shown to bind stoichiometrical amounts of bile salt micelles and to form a binary complex that pancreatic lipase can in turn recognize. It is likely that these binding and recognition processes involve specific conformational changes creating and/ or unveiling appropriate sites on the colipase molecule [11].

The potential of high resolution n.m.r. in describing the conformational rearrangements of proteins under various perturbing factors $(\mathrm{pH}$, temperature, ionic strength, ligand binding etc...) is now widely recognized. In this paper, I report and describe the first n.m.r.

\footnotetext{
Abbreviations: n.m.r., Nuclear Magnetic Resonance. DSS, Sodium 2,2-dimethyl-2-silapentane-5-sulfonate. HMDS, Hexamethyldisiloxane. ppm, parts per million.
}

spectra of porcine colipase, obtained with the help of the most recent advances in the instrumentation for high field proton n.m.r. spectroscopy. Several resonances can be ascribed to specific residues or classes of residues and provide useful natural probes to study the conformational dynamics of colipase II in solution.

\section{Material and methods}

Porcine pancreatic colipase II was a generous gift of Mrs. M. Astier and Dr. M. Charles [1]. Fourier Transform n.m.r. spectra were obtained on the Bruker HXS-360 MHz spectrometer located at the Stanford Magnetic Resonance Laboratory (Stanford University California, USA). This spectrometer is interfaced with a Nicolet NIC-80 16K computer equipped with a Nicolet NIC-294 disc system. Protein samples were dissolved in pure $\mathrm{D}_{2} \mathrm{O}$ (Diaprep) at a concentration of $1.5 \mathrm{mM}$. and $\mathrm{pH}$ was adjusted with dilute $\mathrm{NaOD}$ and $\mathrm{DCl}$. The $\mathrm{pH}$ values were measured on a Radiometer pH Meter Model 26 employing a thin combination glass electrode and are given without correction for deuterium isotopic effect. Chemical shifts were measured with respect to HDO and subsequently converted to HMDS by measuring the position of HDO resonance with respect to an external capillary of HMDS. No correction for bulk magnetic susceptibility was applied. For the sake of a better comparison with other n.m.r. studies of proteins, chemical shifts were finally expressed in ppm from DSS. All spectra were recorded at $30^{\circ} \mathrm{C}$ using $5 \mathrm{~mm}$ precision n.m.r. cells (Wilmad). Sensitivity enhancement was achieved using negative exponential multiplication of the free 